\title{
Regulation of Macromolecular Synthesis, Colony Development, and Specific Growth Rate of Achlya bisexualis during Balanced Growth
}

\author{
By D. H. GRIFFIN, W. E. TIMBERLAKE AND J. C. CHENEY \\ Plant Physiology and Biochemistry Research Group, Department of Forest Botany \\ and Pathology, State University of New York College of Environmental \\ Science and Forestry, Syracuse, New York 13210, U.S.A.
}

(Received 30 May 1973; revised 5 July 1973)

\section{SUMMARY}

The growth of Achlya bisexualis Coker \& Couch on four different nitrogen sources was studied. Growth in submerged culture was filamentous and followed exponential growth kinetics. The organism's specific growth rate varied with the nitrogen source and method of agitation.

RNA content of the mycelium increased linearly with the organism's specific growth rate, but its DNA and protein contents remained constant. Differences in specific growth rate caused by the $\mathrm{N}$ sources were directly related to colony radial-growth rate, branching rate, and width of the peripheral growth zone. The distance from the hyphal tip to the first branch decreased to a minimum value with increased specific growth rate. Mycelial RNA content was generally correlated with specific growth rate.

The doubling time of $5 \mathrm{I}$ min observed on casein hydrolysate at $24^{\circ} \mathrm{C}$ is believed to be the fastest recorded for any eucaryote.

\section{INTRODUCTION}

The growth of fungi is usually measured as the increase of colony diameter on agar medium or dry weight increase in submerged culture (e.g. Ryan, Beadle \& Tatum, I943; Pirt, 1967; Trinci I97 $a$ ). The radius of a colony on a solid medium increases linearly with time,

$$
r=K_{r} t+r_{0}
$$

where $r$ is the colony radius, $K_{r}$ the linear extension rate, and $t$ is the time. The organism's dry weight increases logarithmically in submerged culture,

$$
\ln M=\alpha t+\ln M_{0}
$$

where $M$ is the dry weight and $\alpha$ the specific growth rate. For equation (2) to hold the fungus must grow filamentously as dispersed mycelium (Pirt, I966).

The observation that a cell or hypha grows linearly whilst a population or mycelium grows exponentially is accounted for by cell division and branching respectively (Plomley, 1959; Kubitschek, I970; Trinci, I97 $b$; Caldwell \& Trinci, 1973). In mycelial fungi branching is equivalent to cell division since it increases the number of growing points. The mechanisms regulating the growth rate of a fungus may affect both branching and extension. Since it is not known that these two processes are controlled in the same way biochemically, attempts to elucidate the growth-control mechanisms should consider both branching and 
elongation. Trinci and co-workers have begun to analyse fungus growth in this fashion (Trinci, 1969; 1970; 1971 $a, b$; Caldwell \& Trinci, 1973).

The control of RNA synthesis has been especially implicated in regulating growth rate in bacteria (Edlin \& Broda, 1968; Maaløe \& Kjeldgaard, 1966) and animals (Temin, I967; Todaro, Matsuya, Bloom, Robbins \& Green, 1967). The purpose of this paper is to show that the growth rate of the water mould Achlya bisexualis Coker \& Couch can be altered by changing the cultural conditions, and to describe the relationships between linear extension rate, branching, macromolecular composition, peripheral growth zone, and the specific growth rate of the fungus.

\section{METHODS}

Strain 65-I of Achlya bisexualis Coker \& Couch was used. Stock cultures were maintained on YpSs slants (Emerson, I94I) at $10^{\circ} \mathrm{C}$ and transferred every two to four months.

The culture media contained: glucose, $28 \mathrm{mM} ; \mathrm{KH}_{2} \mathrm{PO}_{4}$ (pH 6.5), $0.5 \mathrm{mM} ; \mathrm{MgCl}_{2}, \mathrm{I} \mathrm{mM}$; $\mathrm{CaCl}_{2}$, 0.5 mM; DL-methionine, $0.34 \mathrm{mM} ; \mathrm{H}_{3} \mathrm{BO}_{3}$, I I $\mu \mathrm{M} ; \mathrm{CoCl}_{2} .6 \mathrm{H}_{2} \mathrm{O}, 0.69 \mu \mathrm{M} ; \mathrm{CuSO}_{4}$. $5 \mathrm{H}_{2} \mathrm{O}, 0.32 \mu \mathrm{M} ; \mathrm{Na}_{2} \mathrm{MoO}_{4} .2 \mathrm{H}_{2} \mathrm{O}, 0.4 \mathrm{I} \mu \mathrm{M} ; \mathrm{MnCl}_{2} .4 \mathrm{H}_{2} \mathrm{O}, \mathrm{I} \cdot 8 \mu \mathrm{M} ; \mathrm{ZnSO}_{4} \cdot 7 \mathrm{H}_{2} \mathrm{O}, 0.36 \mu \mathrm{M}$. The various $\mathrm{N}$ sources were provided at approximately equal $\mathrm{N}$ content as follows: L-glutamic acid (neutralized to $\mathrm{pH} 6$ with $\mathrm{KOH}$ ), $27 \mathrm{~mm}$; ammonium tartrate, $13.5 \mathrm{~mm}$; glycine, $27 \mathrm{~mm}$; casein hydrolysate (enzymically hydrolysed, Nutritional Biochemicals Co., $\mathrm{I} 2 \cdot 7 \% \mathrm{~N}), 2.5 \mathrm{~g} / \mathrm{l}$. Agar, when incorporated, was Difco-Bacto Agar provided at $\mathrm{I} 5 \mathrm{~g} / \mathrm{l}$. The media were sterilized by autoclaving with the glucose, $\mathrm{MgCl}_{2}$ and $\mathrm{CaCl}_{2}$ autoclaved separately at $10 \times$ final concentration and added to the remainder of the medium after cooling.

Spores for inoculum were prepared as by Griffin \& Breuker (I969). Cultures were inoculated with $2.5 \times 10^{6}$ spores $/ 1$.

Three different conditions of agitation were used: (i) cultures in $40 \mathrm{ml}$ of medium in $250 \mathrm{ml}$ Erlenmeyer flasks plugged with cotton placed on a reciprocal shaker at 90 oscillations/min with a $4^{.} \mathrm{I} \mathrm{cm}$ throw; (ii) cultures in $\mathrm{I} \cdot 51$ of medium in 21 Erlenmeyer flasks capped with aluminium foil placed on a rotary shaker at $140 \mathrm{rev} . / \mathrm{min}$ with a $2.5 \mathrm{~cm}$ diameter of rotation; and (iii) stirring in a New Brunswick Fermenter with two impeller blades at $400 \mathrm{rev}$./min and air flow from below the impellers at $101 / \mathrm{min}$ in 4.51 of medium in a 7.51 fermenter vessel. All flasks and the fermenter vessel were treated with dimethyldichlorosilane (Eastman Organic Chemicals) to prevent mycelium from sticking to the glass. The cultures were maintained at $24^{\circ} \mathrm{C}$.

Dry weight measurements were made by filtering a measured sample of the culture onto a previously dried and tared Whatman no. I filter paper and drying to constant weight at $60{ }^{\circ} \mathrm{C}$. Linear extension, branching and peripheral growth zones were measured on colonies growing on the appropriate agar medium in $10 \mathrm{~cm}$ Petri dishes. The radial growth rates of colonies $\left(K_{\mathrm{r}}\right)$ were determined by measuring colony diameters at right-angles to each other. Ten such pairs of measurements were made over a $48 \mathrm{~h}$ period for the casein hydrolysate and glutamate media, and over a $96 \mathrm{~h}$ period for the ammonium tartrate and glycine media. The linear extension, $K_{r}$, was calculated from these data by the least-squares method. Branching was determined by cutting two sectors from each of four plates at intervals over the same time periods mentioned above, fixing these in $4 \%(w / w)$ aqueous formalin, heating them at $80^{\circ} \mathrm{C}$ to separate the agar from the mycelium, and then examining a portion of the mycelium microscopically. The distance from the apex of a hypha to its first branch and the number of branches on the hypha over $500 \mu \mathrm{m}$ from the first branch were determined for 25 hyphae from each plate, for a total of 200 hyphae. The peripheral growth zone was 


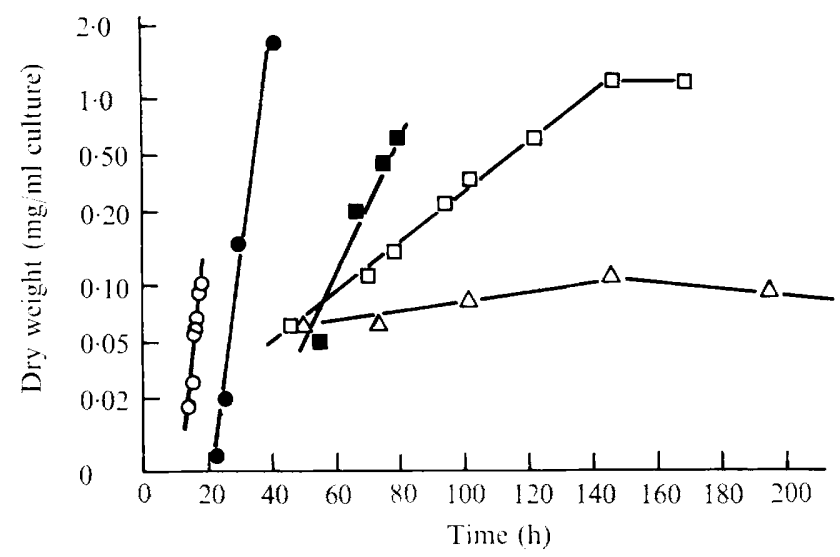

Fig. I. Kinetics of reciprocally shaken cultures grown on different $\mathbf{N}$ sources. Dry weights are the average of four $40 \mathrm{ml}$ cultures harvested at each time. $\mathrm{O}-\mathrm{O}$, Casein hydrolysate; $-\mathrm{O}^{\mathrm{L}-}$ glutamate; $\square-\square$, ammonium tartrate; $\square-\square$, glycine; $\triangle-\triangle$, control lacking $N$ source.

Table I. Specific growth rates/h of Achlya bisexualis in submerged culture

\begin{tabular}{llllc} 
Agitation & \multicolumn{4}{c}{ Nitrogen source } \\
\cline { 2 - 3 } $\begin{array}{c}\text { Casein } \\
\text { hydrolysate }\end{array}$ & $\begin{array}{c}\text { Potassium } \\
\text { glutamate }\end{array}$ & $\begin{array}{c}\text { Ammonium } \\
\text { tartrate }\end{array}$ & Glycine \\
Reciprocally shaken & $0.347 \pm 0.077$ & $0.172 \pm 0.027$ & $0.0977 \pm 0.0234$ & $0.0412 \pm 0.0046$ \\
Fermentor vessel & $0.339 \pm 0.0102$ & $0.230 \pm 0.0336$ & $0.0928 \pm 0.0900$ & $0.0398 \pm 0.0230$ \\
Rotary shaken & $0.806 \pm 0.0788$ & $0.364 \pm 0.110$ & $0.223 \pm 0.0025$ & $0.0767 \pm 0.0361$
\end{tabular}

determined after the method of Trinci (I97I $a$ ). The plates were inoculated with spores in a line across a diameter of the plate, and incubated until the colony was 2 to $3 \mathrm{~cm}$ wide. Two diagonal cuts were made from the edge of the colony to the centre with a sterile scalpel, and a triangular segment of the colony with the vertex at the centre line of inoculation was removed. The image of the colony was projected onto the wall with a $3 \mathrm{M}$ overhead projector to give $6.9 \times$ magnification. By tracing the image of the cut edge and the colony margin at intervals over a 4 to $8 \mathrm{~h}$ period the distance from the cut to the original colony margin was determined at the closest point at which no inhibition of growth occurred. This distance was taken as the peripheral growth zone.

RNA (Griffin \& Breuker, 1969), DNA (Giles \& Myers, 1965), and protein (Lowry, Rosebrough, Farr \& Randall, I95I) were measured as previously described.

Statistical methods were taken from Miller \& Freund (I965).

\section{RESULTS}

Achlya bisexualis grew filamentously under all conditions of submerged culture and increased in dry weight exponentially. Growth in $40 \mathrm{ml}$ reciprocally shaken cultures is shown to illustrate this (Fig. I). A control without $\mathrm{N}$ source other than the methionine, which provides $\mathrm{S}$, indicated that growth was dependent on the $\mathrm{N}$ source (Fig. I). Several other amino acids (asparagine, alanine, leucine, lysine) yielded $\alpha$ 's similar to glutamate, which was chosen as representative of this middle range of growth rates. The specific growth 


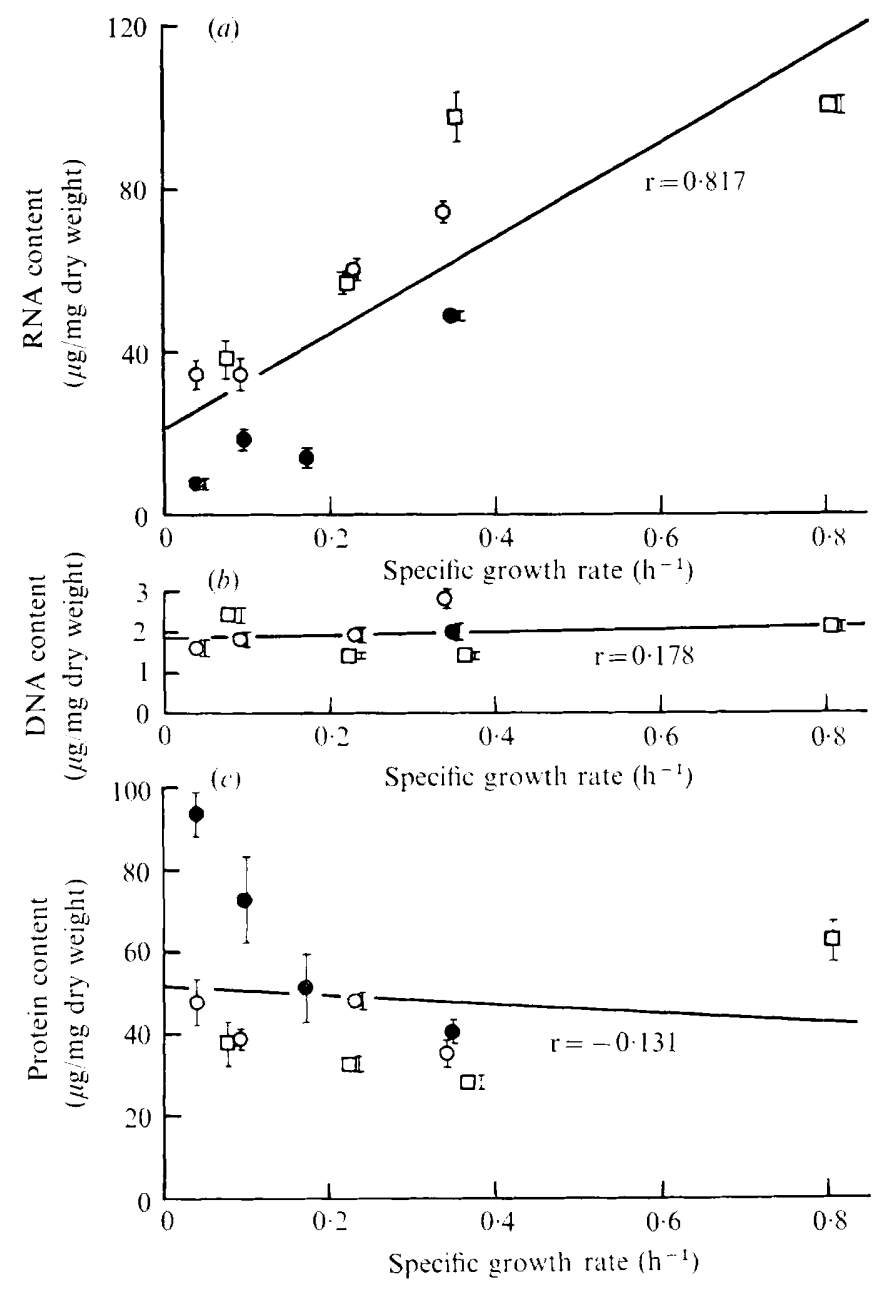

Fig. 2. Macromolecular composition of Achlya bisexualis grown on different $\mathrm{N}$ sources and under different agitation regimes. -0 , reciprocally shaken; $\bigcirc-O$, fermenter vessel; $\square-\square$, rotary shaken. (a) RNA content; $(b)$ DNA content; $(c)$ protein content. The vertical bars at each point are the standard error of estimate; the least-squares best-fit lines are drawn. The values of $r$ indicate the fraction of the variability accounted for by changes in specific growth rate.

rates of the organism on each of the $\mathrm{N}$ sources under the three agitation conditions are shown in Table I. Because it is not clear what factors in the agitation conditions were affecting growth, it should be pointed out that in a preliminary experiment in the fermenter the organisms's specific growth rate was not altered by increasing aeration and stirring respectively from $101 / \mathrm{min}$ and $400 \mathrm{rev} . / \mathrm{min}$ to $161 / \mathrm{min}$ and $600 \mathrm{rev} . / \mathrm{min}$.

The data on DNA, RNA, and protein synthesis are shown in Fig. 2. Each point represents the average of four to eight determinations taken during the course of growth-curve measurements. Since the macromolecular content/mg dry wt was nearly constant throughout growth, these components of the fungus increased exponentially with dry weight. The correlation coefficient, $r$, is shown and is significant at the 0.005 level of probability for RNA by the $z$ test. The $r$ values for DNA and protein content indicate no correlation with specific growth rate. 


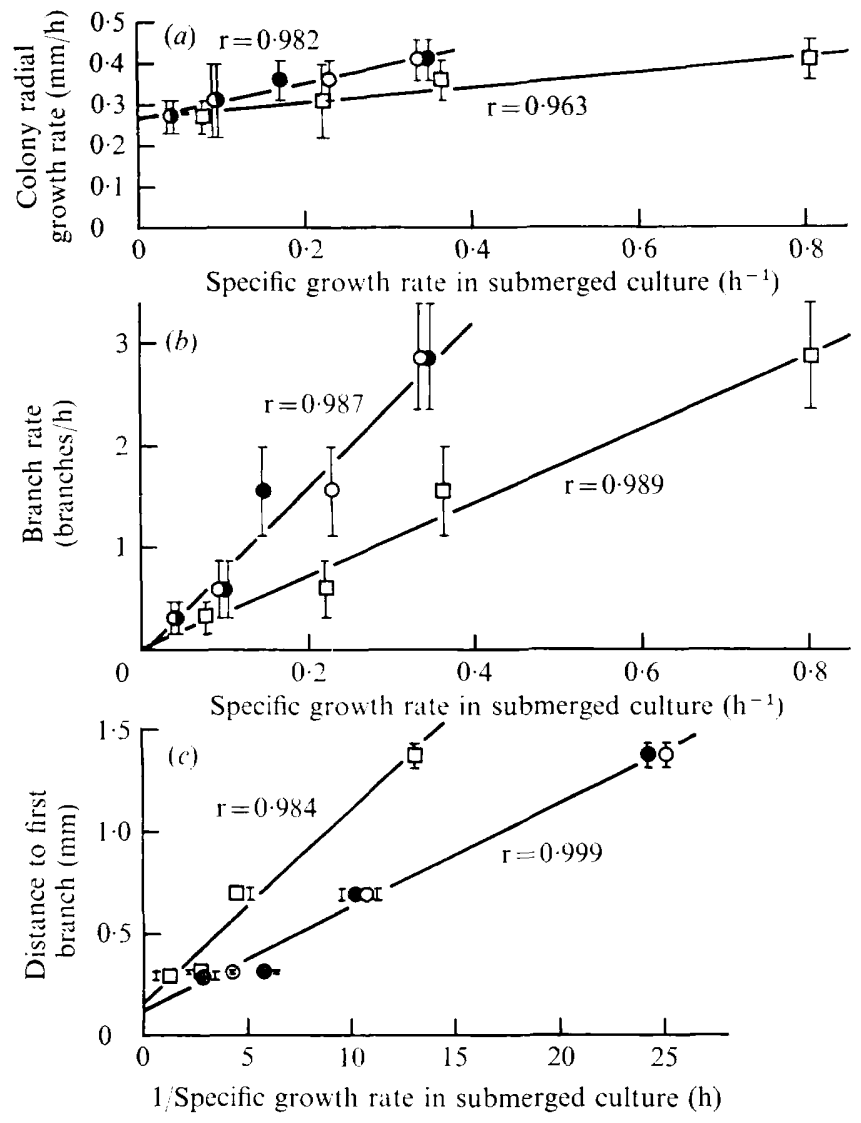

Fig. 3. Colony development parameters of Achlya bisexualis grown on different N sources graphed against specific growth rate in the same medium under different agitation regimes. Reciprocally shaken; $\bigcirc-0$, fermenter vessel; $\square-\square$, rotary shaken. (a) Colony radial growth rate: $(b)$ branching rate: $(c)$ distance from hyphal tip to the first branch, plotted against $\alpha^{-1}$. The vertical bars at each point are the standard error of estimate; the least-squares best-fit lines are drawn. The values of $r$ indicate the fraction of the variability accounted for by changes in specific growth rate.

The data on colony radial-growth rate, branching rate, distance from the hyphal tip to the first branch, and width of the peripheral growth zone are shown in Fig. 3 and 4. The distance to the first branch, $F$, is plotted against the reciprocal of the specific growth rate. The correlation coefficient for each line is shown and is significant at the 0.05 level. The branching rates indicated in Fig. $3 b$ are calculated as the product of the linear extension rate and the branch-density measurements.

\section{DISCUSSION}

The specific growth rate of Achlya bisexualis, strain 65-I, can be regulated by the nitrogen source provided. Growth was balanced, i.e. DNA, RNA, and protein increased exponentially, maintaining a constant proportion in the mycelium.

That branching, width of the peripheral growth zone and RNA content of the mycelium were very much affected by the nitrogen source, suggests that these factors were more 


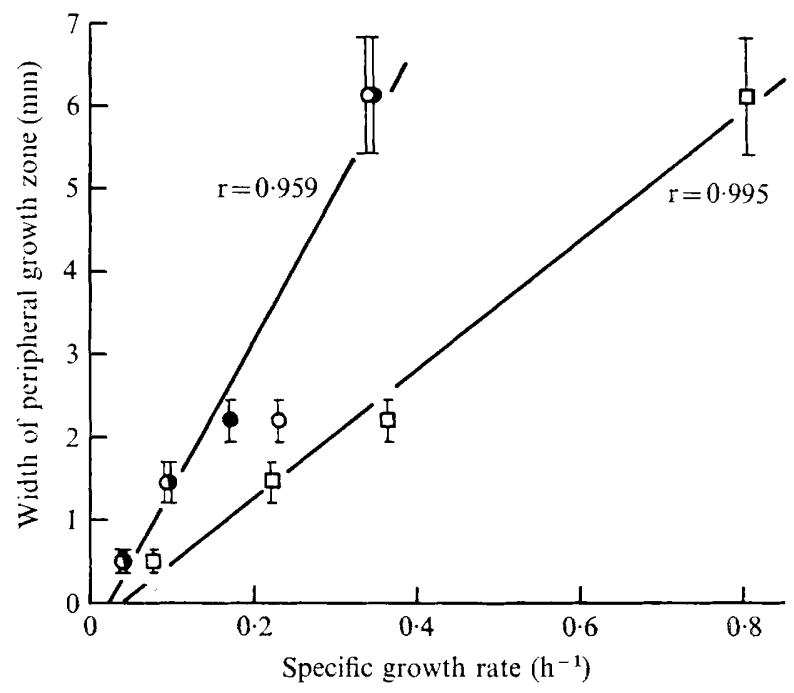

Fig. 4. Width of the peripheral growth zone of Achlya bisexualis grown on different $\mathrm{N}$ sources graphed against specific growth rate in the same medium under different agitation regimes. - Reciprocally shaken; $\bigcirc-\bigcirc$, fermenter vessel; $\square-\square$, rotary shaken. The vertical bars at each point are the standard error of estimate; the least-squares best-fit lines are drawn. The values of $r$ indicate the fraction of the variability accounted for by changes in specific growth rate.

closely related to the growth control mechanism than to the colony radial-growth rate and DNA and protein content. While there was a significant linear correlation of colony radialgrowth rate to specific growth rate, the effect of $\mathrm{N}$ source on radial'growth was small and did not reflect the magnitude of the effect of $\mathrm{N}$ source on specific growth rate. Trinci (I97I $a$ ) has also shown that colony radial-growth rate was useless for comparing the growth of different fungi and for determining the effect of nutrient concentration on growth rate.

Two factors concerning branching were affected by the $\mathrm{N}$ source: the distance to the first branch, and the rate of branching after the first branch. The former decreased to a minimum as specific growth rate increased, as shown by the graph of $F$ against $\alpha^{-1}$. The $F$ intercept as $\alpha \rightarrow \infty\left(\alpha^{-1} \rightarrow 0\right)$ suggests minimum branch distances of II $3 \pm 70 \mu \mathrm{m}$. Apical dominance may be involved in this phenomenon.

We can consider these data in the light of Plomley's (1959) concept of a growth unit. It is evident that the length of mycelium required to maintain the growth of the leading hyphae (width of the peripheral growth zone) is greater for faster growth rates. However, this is complicated by the increased branch density and the fact that branches areformed closer to the tip at higher specific growth rates. The number of primary branches on a single hypha within its peripheral growth zone was $4 \mathrm{I}$ on casein hydrolysate, 8.2 on glutamate, I.5 on ammonium, and o on glycine (calculated from the data in Fig. 3 and 4). It is clear that the length of hypha per branch was much less at higher specific growth rates, and functional growth units, if indeed one can retain this concept at all, must be overlapping. The same protoplasm is required for the maintenance of several hyphal tips. The concentration of RNA increased in support of increased specific growth rate, but that of DNA and protein did not. This is in general agreement with the data of Schaechter, Maaløe \& Kjeldgaard (1958) for Salmonella typhimurium. They showed that RNA content was an 
exponential function of specific growth rate. However, this allows us to draw similar conclusions, namely that the ribosomes are all functioning at maximal rates and it is necessary to increase the number of ribosomes to support faster growth. On the other hand, template was not limiting since the DNA concentration remained constant. The relative transcriptional rate must increase without an increase in total template. This suggests that transcriptional control is a limiting factor in the regulation of growth. The study of the regulation of the RNA polymerases should prove fruitful.

Although the effect of agitation in these experiments is not completely understood, it was reproducible with all of the $\mathrm{N}$ sources. Increasing the aeration and stirring in the fermenter vessel, where the agitation must result in quite efficient gas exchange with the medium, had little effect; this suggests that $\mathrm{O}_{2}$ supply was not limiting growth rate. If anything, the rate of supply of $\mathrm{O}_{2}$ must have been lowest in the rotary shake cultures which were in 21 Erlenmeyer flasks filled with $\mathrm{I} \cdot 5 \mathrm{l}$ of medium. Perhaps $\mathrm{CO}_{2}$ accumulated in these flasks and led to higher growth rates. The observation of Trinci ( $197 \mathrm{I} b$ ), that germ-tube specific growth rate was higher than the mycelial specific growth rate, might be due to the closed system used for measuring germ-tube growth wherein $\mathrm{CO}_{2}$ could accumulate.

The doubling time of 5I min observed in casein hydrolysate medium at $24{ }^{\circ} \mathrm{C}$ probably qualifies Achlya bisexualis as the fastest eucaryote on record (cf. Trinci, 1972, who reports a doubling time for Geotrichum candidum of $66 \mathrm{~min}$ at $30^{\circ} \mathrm{C}$ ).

We thank Dr D. C. Goodman, Department of Anatomy, Upstate Medical Center, for the loan of the New Brunswick Fermenter, and C. Vogel for technical assistance.

\section{REFERENCES}

Caldwell, 1. Y. \& Trinci, A. P. J. (1973). The growth unit of the mould Geotrichum candidum. Archiv für Mikrobiologie 88, I-10.

Edlin, G. \& Broda, P. (I968). Physiology and genetics of the 'ribonucleic acid control' locus in Escherichia coli. Bacteriological Reviews 32, 206-226.

EMERSON, R. (I94I). An experimental study of the life cycles and taxonomy of Allomyces. Lloydia 4, 77-144.

GiLes, K. W. \& Myers, A. (1965). An improved diphenylamine method for the estimation of deoxyribonucleic acid. Nature, London 206, 93.

GrifFIN, D. H. \& BREUKER, C. (I969). Ribonucleic acid synthesis during the differentiation of sporangia in the water mold Achlya. Journal of Bacteriology 98, 689-696.

KUBITSCHEK, H. E. (1970). Evidence for the generality of linear cell growth. Journal of Theoretical Biology 28, I5-19.

Lowry, O. H., Rosebrough, N. J., Farr, A. L. \& Randall, R. J. (I95I). Protein measurement with the Folin phenol reagent. Journal of Biological Chemistry 193, 265-275.

MaAløe, O. \& KJeldgaArd, N. O. (I966). Control of Macromolecular Synthesis. New York: W. A. Benjamin.

Miller, I. \& Freund, J. E. (1965). Probability and Statistics for Engineers. Englewood Cliffs, New Jersey: Prentice-Hall.

PIRT, S. J. (I966). A theory of the mode of growth of fungi in the form of pellets in submerged culture. Proceedings of the Royal Society B r66, 369-373.

PIRT, S. J. (1967). A kinetic study of the mode of growth of surface colonies of bacteria and fungi. Journal of General Microbiology 47, 18 I-I97.

Plomley, N. J. B. (1959). Formation of the colony in the fungus Chaetomium. Australian Journal of Biological Sciences I2, 53-64.

Ryan, F. J., Beadle, G. W. \& Tatum, E. L. (I943). The tube method of measuring the growth rate of Neurospora. American Journal of Botany 30, 784-799.

Schaechter, M., Maaløe, O. \& KJeldgaard, N. O. (I958). Dependency on medium and temperature of cell size and chemical composition during balanced growth of Salmonella typhimurium. Journal of General Microbiology 19, 592-606. 
Temin, H. M. (1967). Control by factors in serum of multiplication of uninfected cells and cells infected and converted by avian sarcoma viruses. Wistar Institute Symposium Monograph 7, 103-116.

Todaro, G., Matsuya, Y., Bloom, S., Robbins, A. \& Green, H. (1967). Stimulation of RNA synthesis and cell division in resting cells by a factor present in serum. Wistar Institute Symposium Monograph 7 , 87-10I.

TrincI, A. P. J. (1969). A kinetic study of the growth of Aspergillus nidulans and other fungi. Journal of General Microbiology 57, I I-24.

TrINCI, A. P. J. (1970). Kinetics of apical and lateral branching in Aspergillus nidulans and Geotrichum lactis. Transactions of the British Mycological Society 55, I7-28.

TRINCI, A. P. J. (I97I a). Influence of the width of the peripheral growth zone on the radial growth rate of fungal colonies on solid media. Journal of General Microbiology 67, 325-344.

TrincI, A. P. J. (I97I b). Exponential growth of the germ tubes of fungal spores. Journal of General Microbiology 67, 345-348.

Trinci, A. P. J. (1972). Culture turbidity as a measure of mould growth. Transactions of the British Mycological Society 58, 467-473. 